\title{
Flood generation and destruction of "Drift" Glacier by the 1989-90 eruption of Redoubt Volcano, Alaska
}

\author{
D. C. TRABAnT \\ U.S. Geological Survey, 800 Yukon Drive, Fairbanks, AK 99775, U.S.A. \\ AND D. F. MEYER \\ U.S. Geological Survey, 4230 University Avenue-Suite 201, Anchorage, AK 99508, U.S.A.
}

\begin{abstract}
Mid-winter flooding of the Drift River was caused by melting of snow and glacier ice during the 1989-90 eruption of Redoubt Volcano. "Drift" Glacier (unofficial name) was beheaded when 110 to $120 \times 10^{6} \mathrm{~m}^{3}$ of perennial snow and ice were mechanically entrained by the four largest volcanically initiated flows. The flow volumes were increased by incorporation of the seasonal snowpack on the lower glacier surface and in the flooded river valley. The seasonal snow contributed a volume equivalent to about $35 \times 10^{6} \mathrm{~m}^{3}$ of water to the flows, increasing the cumulative flood volume by almost $30 \%$. No large amounts of meltwater were stored on or under the glacier before any of the flows took place. The threat of flooding was significantly reduced after the second major eruption removed the remainder of the easily erodible snow and ice.
\end{abstract}

\section{INTRODUGTION}

Redoubt Volcano, about $177 \mathrm{~km}$ southwest of Anchorage, Alaska (Fig. 1), is near the northeastern end of the Aleutian volcanic arc. The glacier-clad volcano is a composite cone with a $1.8 \mathrm{~km}$ wide, ice-filled summit crater at about $2550 \mathrm{~m}$ altitude. "Drift" Glacier drains the summit area through a breach in the northern crater rim and plunges down a chaotic icefall to the head of its piedmont lobe at about $650 \mathrm{~m}$ altitude. The piedmont lobe is $3.5 \mathrm{~km}$ long and its terminus at $300 \mathrm{~m}$ altitude abuts the Drift River. Redoubt Volcano experienced 20 explosive events between 14 December 1989 and 21 April 1990 from a volcanic vent that was under "Drift" Glacier at about $2400 \mathrm{~m}$ altitude. The eruption beheaded "Drift" Glacier, ultimately removing most of the glacier ice between 750 and $2400 \mathrm{~m}$ altitude. The most recent previous eruptive series, in 1966-68, also beheaded "Drift" Glacier, removing about $60 \times 10^{6} \mathrm{~m}^{3}$ of glacier ice (Sturm and others, 1986).

The 1989-90 mid-winter flows of snow and ice, volcaniclastic debris, alluvial material, and meltwater generated by the four most energetic eruptions of Redoubt Volcano caused flooding along the Drift River from the base of the volcano to Cook Inlet. The volcanically induced melting and disruption of snow and ice materials were confined to "Drift" Glacier and within the Drift River valley downstream from the glacier. Beyond the terminus of the glacier, flows dropped much of their sediment load (debulked) and were attenuated along the more gently sloping flood plain of the river. Nevertheless, the floods forced several temporary evacuations of an oil-storage and tanker- loading facility near the mouth of the river, $34 \mathrm{~km}$ from the volcano (Brantley, 1990).

This report elucidates the general processes of fluidization of snow and ice materials that occurred during the four largest eruptions of Redoubt Volcano during 1989-90. Eruptions of glacier-clad volcanos worldwide, the interaction of eruptions with the snow and ice, and the formation of flows and deposits have been summarized by Major and Newhall (1989). Their summary contains ten references to snow and ice inclusions in volcanogenic flows. Their synopsis shows that the processes recognized at Redoubt Volcano might have been active during eruptions elsewhere. The original objective of the field study was to improve flood hazard predictions during the course of the eruption, by assessing the relation between volcanic activity and the changing distribution of snow and ice materials.

The generic term "flow" used in this report refers to a fluidized mass of debris which undergoes relatively rapid changes in composition and rheology. Typically, such flows begin when avalanches of hot rock and gas (pyroclastic, surge, debris, etc.) incorporate and deposit simultaneously varying amounts of snow, ice, and older rocks as they move along their path. Thus, the flows are cooled and generally increase in water content as they change from debris flow to hyperconcentrated flow and, finally, water-dominated flow (Major and Newhall, 1989).

\section{MEASUREMENTS AND DATA}

Analysis of the eruption-induced changes in snow and ice 
volume of "Drift" Glacier following the four principal eruptions was based on ground and aerial field observations and videos, oblique and vertical aerial photography, snow pits, and ice-thickness measurements. Intensified photo and video coverage of Redoubt Volcano began on 14 December 1989 immediately before the onset of eruptive activity and continued on most good-weather days through the first three months of the eruption. Two time-lapse camera systems began photographic records on 22 March and 22 May 1990. Four sets of large format, vertical aerial photographs were made on 9 January, 5 May, 31 May and 29 August 1990. Two snow-pit studies along the Drift River valley and three more in unperturbed areas on the piedmont lobe of "Drift"

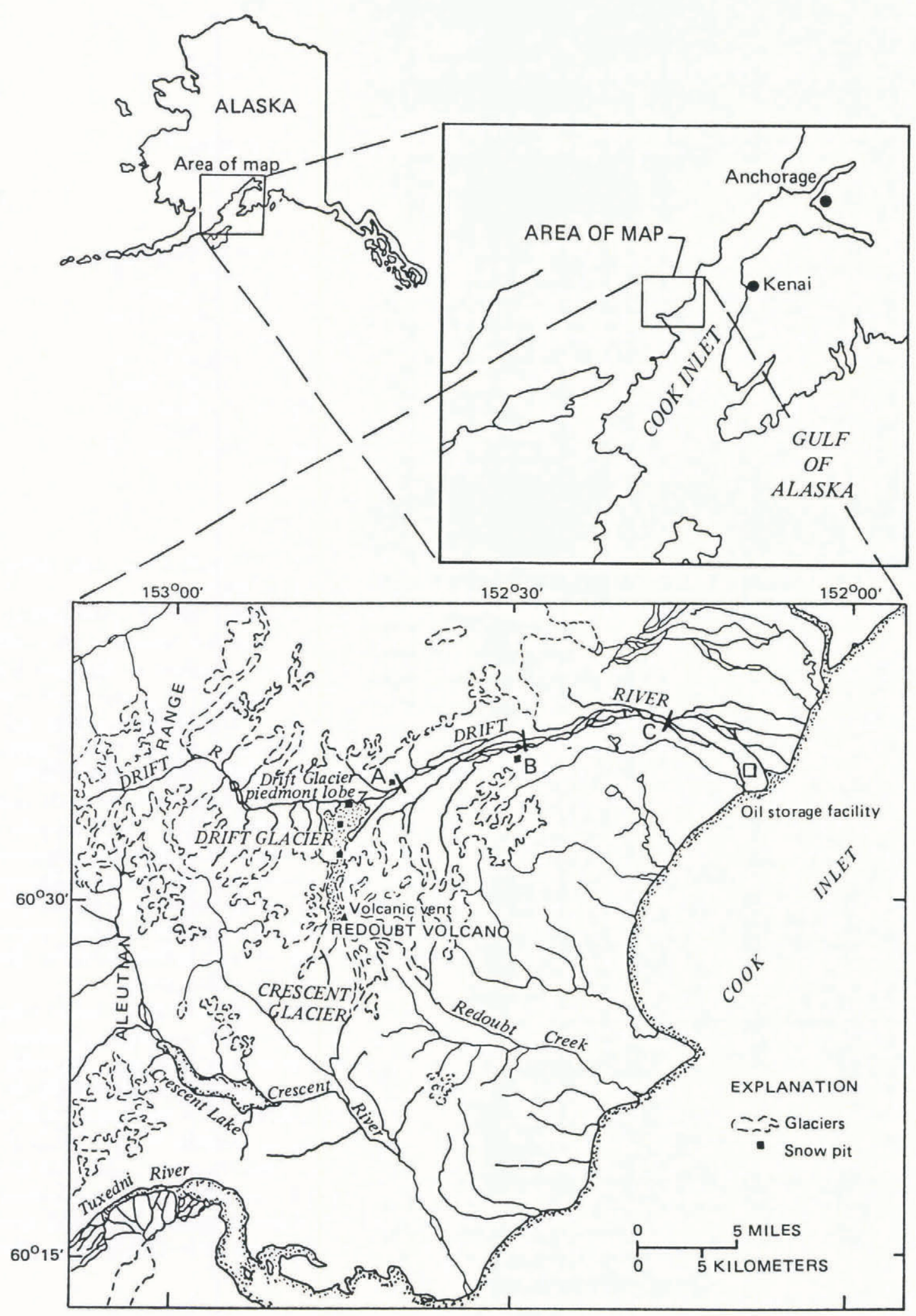

Fig. 1. Location of Redoubt Volcano, volcanic vent, and oil-storage and tanker-loading facility. River cross-sections labeled " $A$ ", " $B$ ", and " $C$ " and snow-pit study sites. 


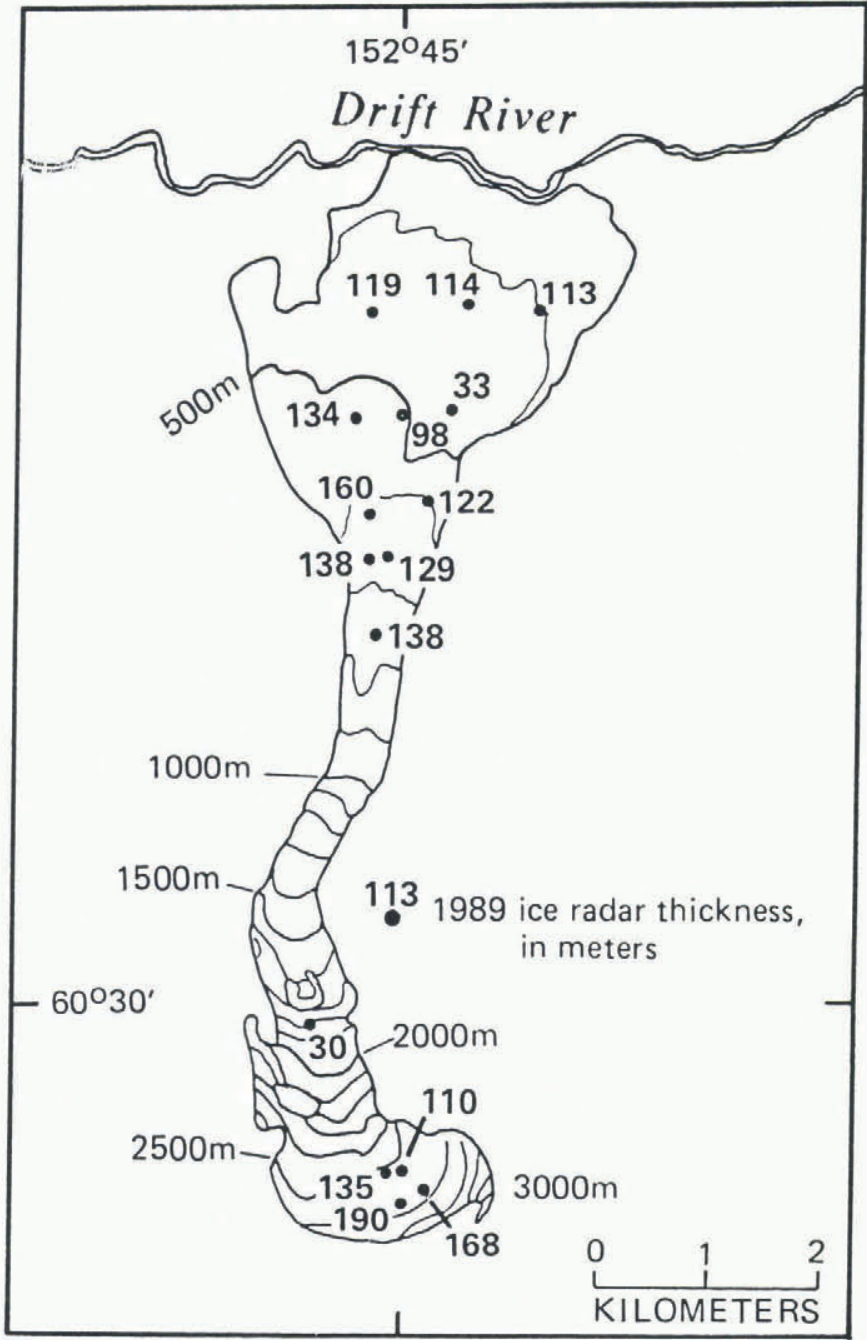

Fig. 2. Ice radar thickness measurement sites on "Drift" Glacier (circles), with ice thickness in meters. Glacier surface contour interval is $100 \mathrm{~m}$.

Glacier (Fig. 1) were analyzed to determine the water equivalent of the snow between the ash layers from the four major 1989-90 eruptions; these were used to estimate the volume of water incorporated in the flows that swept the glacier surface and valley bottom down to its exit from the mountains. Sixteen ice-radar thicknesses had been measured on "Drift" Glacier four months before volcanic activity began (Fig. 2) as part of a hazard assessment study.

The range of volume change values in the text represents the errors assignable to the digital analytical technique used to determine the volumes. The absolute errors have not been rigorously assessed owing to incomplete geodetic control and unfinished remapping of the area. The final adjustments are not expected to cause changes in the order of magnitude of these values.

Flood volumes and maximum discharges for each of the four major eruptions were estimated from three repeatedly measured floodway cross-sections (Fig. 1), run-up measurements on trees and lateral banks, and rheologies based on analysis of flow deposits.

\section{GHRONOLOGY AND INTERPRETATION OF MAJOR ERUPTIONS AND FLOWS}

\section{Pre-eruption}

Photographs made immediately before the vent-clearing eruption on 14 December show a circular opening in the ice and snow around the lava dome left by the 1966 eruption. "Drift" Glacier had completely covered the 1966 dome for several years. The open moat in the snow and perennial ice in the immediate vicinity of the old dome had an estimated volume of 13 to $14 \times 10^{6} \mathrm{~m}^{3}$. There was no evidence of large amounts of meltwater storage in the moat around the dome or of increased runoff from the volcano at that time; it is assumed that the meltwater entered the volcano's ground-water system and some was lost as vapour. Pilots reported sighting steam "clouds" on 20 November and 3 December 1989; a steam plume was visible from Anchorage on 8 December 1989 (Brantley, 1990).

\section{4 and 15 December 1989}

A series of four explosive eruptions on 14 and 15 December removed an additional 65 to $67 \times 10^{6} \mathrm{~m}^{3}$ of snow and perennial ice from the summit crater and connecting outlet glacier, producing a succession of debris avalanches and debris flows. The avalanches were mixtures of snow, slush, ice, old rock and juvenile volcanic debris. Photos and reconnaissance flights revealed no evidence of subsidence crevasses, which would indicate release of a large volume of subglacially stored meltwater. This avalanche and flow beheaded "Drift" Glacier. It removed the roughest and steepest glacier ice and snow at 2200 to $1500 \mathrm{~m}$ altitude and established deeply incised channels in the smoother glacier ice at 1500 to $600 \mathrm{~m}$ altitude. The incised channels were 10 to $30 \mathrm{~m}$ wide, 10 to $40 \mathrm{~m}$ deep and terminated on the east edge of the glacier at about $600 \mathrm{~m}$ altitude. Most of the disrupted snow and ice were mechanically incorporated by the avalanches of pyroclastic material as they descended a highly crevassed, $1700 \mathrm{~m}$ high icefall.

On the north side of Redoubt Volcano, multiplelayered ice conglomerate deposits (Gardner and Neal, 1990; Waitt and others, 1990a, b) were emplaced by the first eruptions and destroyed by subsequent flows on 14 and 15 December. Most of the deposits occur near the base of the icefall at about $850 \mathrm{~m}$ altitude and extend about $1.5 \mathrm{~km}$ down the east half of "Drift" Glacier (Fig. 3 ), with scattered remnants of ice conglomerates found as high as the volcanic vent at $2400 \mathrm{~m}$. Subsequent erosion cut canyons through the continuous deposit and underlying glacier ice, revealing an average thickness of about $5 \mathrm{~m}$ for the deposit. The lower ice conglomerate deposits began near the mouth of the channel draining the east side of "Drift" Glacier and formed a fan extending downstream for about $2 \mathrm{~km}$. The lower deposits had a maximum thickness of about $10 \mathrm{~m}$. Together, the ice conglomerate deposits had a volume of 14 to $15 \times 10^{6} \mathrm{~m}^{3}$, were 80 to $90 \%$ ice, and amounted to about $20 \%$ of the total volume of snow and ice disrupted by the series of eruptions and flows. 
The eruption-initiated flows on 15 December swept over the piedmont lobe of "Drift" Glacier and down the Drift River valley, entraining the seasonal snowpack, which amounted to an estimated $22 \times 10^{6} \mathrm{~m}^{3}$ of water. A peak discharge of 15 to $20000 \mathrm{~m}^{3} \mathrm{~s}^{-1}$ was estimated $11 \mathrm{~km}$ downstream from the vent (Fig. 1, cross-section A; T. C. Pierson, written communication, 1990). Farther downstream, beyond the mountain front, flooding was constrained by natural levees, $3 \mathrm{~m}$ high, composed of a mixture of river ice and snow. At the oil-storage and tanker-loading facility near the mouth of the river, $34 \mathrm{~km}$ downstream, the top of the natural ice levee was about $3 \mathrm{~m}$ below the top of a flood-diversion dike. A peak discharge of 4000 to $8000 \mathrm{~m}^{3} \mathrm{~s}^{-1}$ was estimated near this facility (T. C. Pierson, written communication, 1990).

The 15 December eruption is the only one that affected any of the other glaciers on the massif significantly. The southwest-flowing "Crescent" Glacier (unofficial name) (Fig. 1) was overridden by a debris flow when pyroclastic eruptive materials spilled over the second lowest part of the crater rim at the head of the glacier. The flow descended a steep, highly crevassed area entraining snow and ice and continued for about one-half

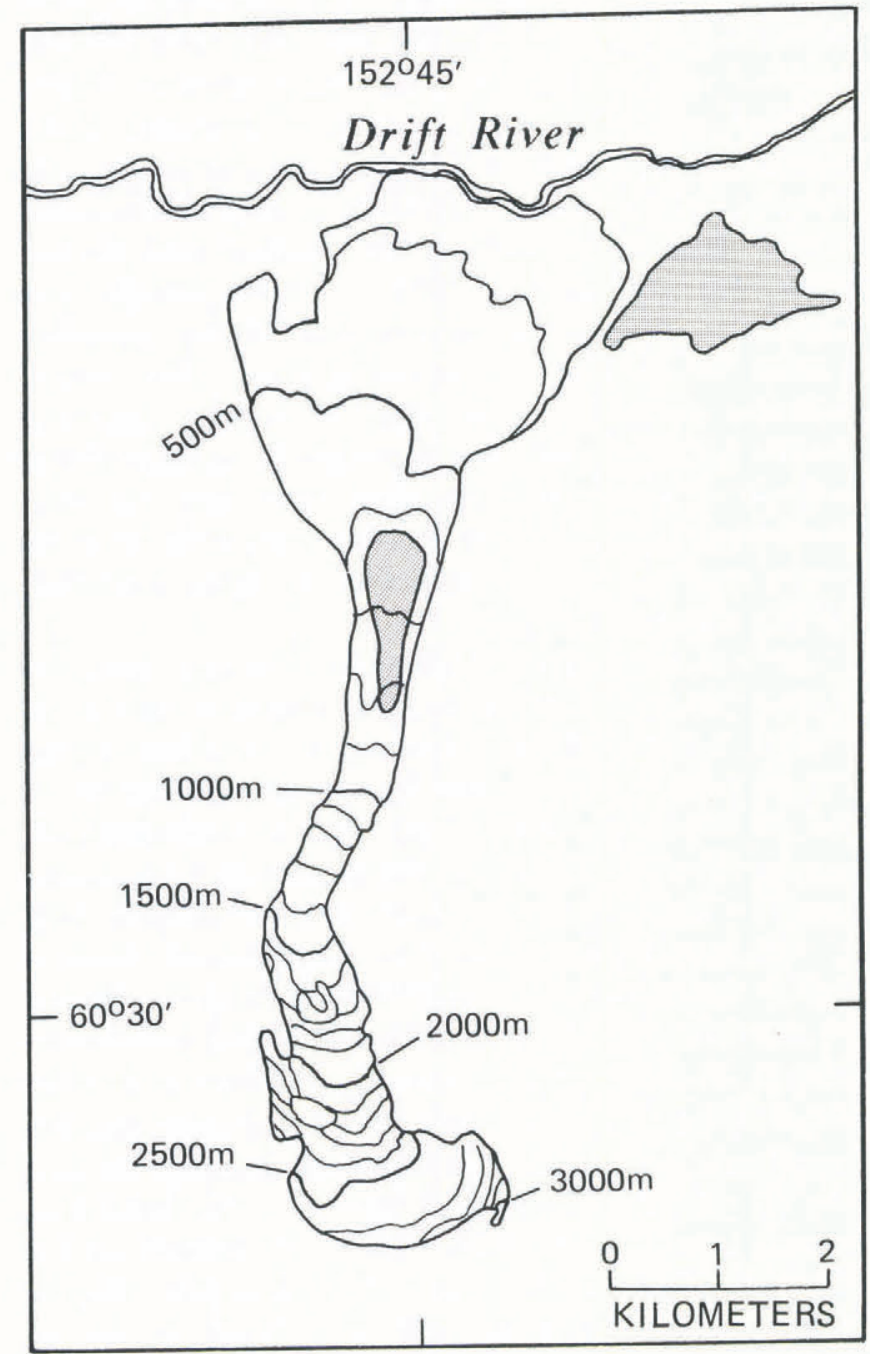

Fig. 3. Ice conglomerate deposits (shaded areas) formed by the first eruptions on 15 December 1989. of the $6 \mathrm{~km}$ length of "Crescent" Glacier. The resulting ice conglomerate deposit was similar to that produced on the north flank with ice conglomerate remnants left from the crater rim down to the head of the main deposit, which began where the surface slope abruptly decreased and then continued to about $900 \mathrm{~m}$ altitude (C. A. Neal, written communication, 1991). This deposit was smaller in areal extent but thicker (as much as $20 \mathrm{~m}$ thick) than those formed on the north side of the massif.

\section{January 1990}

An additional 24 to $25 \times 10^{6} \mathrm{~m}^{3}$ of glacier ice was removed on 2 January when a newly formed volcanic dome collapsed in the most energetic eruption of the 1989-90 series. The hot dome materials flowed down the gorge that had contained the "Drift" Glacier icefall. The resulting pyroclastic flow removed the remnants of glacier ice from between 2200 and $1300 \mathrm{~m}$ altitude, extending the wholesale destruction of "Drift" Glacier to $200 \mathrm{~m}$ lower in altitude. The pyroclastic flows enlarged the channels incised in the remaining glacier ice to 30 to $100 \mathrm{~m}$ widths and reached the full ice thickness of 30 to $100 \mathrm{~m}$ throughout most of their lengths. The flows scoured and melted new snow from the glacier surface and river valley, estimated to be equivalent to $4 \times 10^{6} \mathrm{~m}^{3}$ of water. Discharges estimated using standard clear-water indirect flow-measurement techniques range from $60000 \mathrm{~m}^{3} \mathrm{~s}^{-1}$ between 10 and $20 \mathrm{~km}$ downstream from the volcano (cross-sections A and B, Fig. 1), to $20000 \mathrm{~m}^{3} \mathrm{~s}^{-1}$ between 20 and $30 \mathrm{~km}$ downstream from the volcano (crosssections B and C, Fig. 1). Application of clear-water techniques to debris flows may not be warranted, but these techniques have been applied successfully to other lahars (Laenen and Hansen, 1988). The flood was not constrained by the natural levees formed by the previous flows on the fan, and the flow inundated most of the fan and its distributary channels. Hot boulders of dense dome rock more than $2 \mathrm{~m}$ in diameter were carried the $34 \mathrm{~km}$ length of the river; boulders of coarse crystalline glacier ice up to $5 \mathrm{~m}$ in diameter were abandoned along the entire floodway. Flood waters rose $7.5 \mathrm{~m}$ near the oilstorage and tanker-loading facility at the seaward edge of the fan, about $1 \mathrm{~m}$ below the containment dikes around the storage tanks. The flood flanked the diversion dikes and invaded the rest of the facility.

After the 2 January eruption, the threat of flooding was reduced because the remaining snow and ice in the flow path had much smoother surfaces and lower surface gradients than before 2 January. Between 14 December 1989 and 2 January 1991, about 15\% of "Drift" Glacier and $60 \%$ of the perennial ice mass in the summit crater had been removed by the eruptive activity.

\section{February 1990}

Explosive disintegration of another lava dome on 15 February was the third most seismically energetic eruption of the 1989-90 series and produced a laterally directed pyroclastic surge northward from the crater. The surge deposited hot materials into snow-covered areas that had not previously been invaded. The pyroclastic surge destroyed one of the time-lapse cameras and was 
hot enough to char the surface of woody plants, melt plastics, and kill small animals. However, only thin melt crusts were observed on most snow surfaces away from the glacier piedmont surface and Drift River valley bottom, although hot rock ejecta melted into snow to depths of 10 to $15 \mathrm{~cm}$. The pyroclastic flow destroyed the remnant glacier ice from between 1300 and $750 \mathrm{~m}$ altitude and scoured the incised glacier ice channels, removing an estimated 10 to $15 \times 10^{6} \mathrm{~m}^{3}$ of glacier ice. The flow continued down the Drift River valley, incorporating the recent snow that was estimated equivalent of $7.5 \times 10 \mathrm{~m}^{3}$ of water. The estimated peak discharge was $20000 \mathrm{~m}^{3} \mathrm{~s}^{-1}$ between 10 and $20 \mathrm{~km}$ downstream from the crater, and $5000 \mathrm{~m}^{3} \mathrm{~s}^{-1}$ between 20 and $30 \mathrm{~km}$ downstream from the crater.

\section{March 1990}

The most significant eruption following the pyroclastic surge of 15 February occurred on 14 March; it made relatively small changes in the glacier ice and produced a peak discharge of about $2500 \mathrm{~m}^{3} \mathrm{~s}^{-1}, 22 \mathrm{~km}$ from the volcanic vent. The flow incorporated an estimated $2 \times 10^{6} \mathrm{~m}^{3}$ of water equivalent as snow in the flood path.

\section{DISCUSSION AND CONCLUSIONS}

Rapid melting of snow and ice was not necessary to explain the process of entrainment of snow and ice and flood generation by the flows that resulted from the 198990 eruption of Redoubt Volcano. Furthermore, there was no evidence that release of large volumes of subglacially stored water was associated with any of the eruptioninitiated flows. The ice conglomerate deposits represent the cold end member of volcaniclastic flows in which the volcanic materials had insufficient heat energy to melt the entrained ice materials significantly; the flow stopped and solidified rapidly when it reached lower slopes. This suggests that all of the flows might have begun with very low liquid contents, and could have traveled as far as $10 \mathrm{~km}$ down the steepest terrain before the presence of liquids was necessary to sustain motion over lower gradients. This extends the time available for effective heat transfer and melting.

The destruction of "Drift" Glacier was principally by mechanical disaggregation and rapid entrainment of snow and glacier ice by avalanches of hot rock, ash, and gases. Evidence for mechanical disaggregation and entrainment of the ice of "Drift" Glacier was found in ice conglomerate deposits and large-diameter glacier-ice boulders that were carried by the debris flows. The ice conglomerate deposits contained boulders of both formerly hot juvenile rocks (the boulders were prismatically fractured indicating rapid cooling) and coarse, crystalline, glacier ice that were as much as $0.5 \mathrm{~m}$ in diameter frozen in an ice matrix with smaller, more angular fragments of rock, pumice, and glacier ice. The upper 1 to $2 \mathrm{~m}$ of the deposits were of lower density, apparently because of some water draining into lower parts of the deposit. The lower parts of the deposits were saturated thoroughly and frozen solidly. Two observations suggest that the mixture was a cold slurry that froze rapidly: (1) the previously hot rocks did not sink after the deposit ceased motion and (2) flows less than $25 \mathrm{~h}$ later eroded sharp-edged canyons through the deposits, carrying boulders of the ice conglomerate up to $4 \mathrm{~m}$ in diameter for a distance of $5 \mathrm{~km}$ downstream. Mechanical disaggregation of "Drift" Glacier was also affirmed by the presence of boulders of coarse, crystalline glacier ice, up to $10 \mathrm{~m}$ in diameter, that littered the Drift River valley floor. Glacier-ice boulders as large as $5 \mathrm{~m}$ were carried as far as $30 \mathrm{~km}$ down the Drift River.

The first eruptions spawned the ice conglomerate deposits because disaggregation and entrainment of snow and glacier ice were enhanced by the steep, highly crevassed icefall over which the pyroclastics moved. The steep, rough icefall tended to minimize the critical shear stress necessary for mobilizing the glacier-ice materials and to maximize the shear stress imposed by the pyroclastic flow by increasing the effect of turbulence. These processes resulted in rapid cooling of the eruptive materials as the composition of the avalanche became dominantly snow and glacier ice. The observation that successive pyroclastic flows contained decreasing volumes of glacier ice supports the premise that mechanical entrainment was an important process because the decreasing entrainment volumes corresponded directly with the decreasing area of steep, rough ice surfaces. The reduced snow and glacier ice entrainment also marks the transition from the ice-dominated flows, which produced the ice conglomerate deposits, to the ice-entraining debris flows, which produced the debris flow deposits down the entire length of the Drift River. The decreasing volumes of entrained glacier ice were not simply due to the total destruction of the glacier or the lack of ice along the flow path. All the eruption-initiated flows traveled over the piedmont lobe and through the incised channels of lower "Drift" Glacier; that is, ice was always available along the flow path. Indeed, by the end of May 1990, less than 10\% of the total ice volume of "Drift" Glacier had been removed. However, the remaining glacier ice had lower surface slopes and smoother surfaces, in spite of the incised channels. This reduced the shear stresses imposed by overriding flows and explained the reduced mechanical entrainment.

The ice-rich ice conglomerate deposits will leave little evidence of their existence in the geologic record after the ice has melted. This process might explain why such deposits are seldom recognized. All seven of the historic eruptions of Redoubt Volcano have occurred in winter, yet no previous ice conglomerate deposits have been identified.

The 1989-90 eruption of Redoubt Volcano removed 110 to $120 \times 10^{6} \mathrm{~m}^{3}$ of perennial ice and snow from "Drift" Glacier. If the mean density of the disrupted snow and ice was $0.8 \mathrm{Mg} \mathrm{m}^{3}$ (adjusting for severely crevassed surfaces as well as snow), the disrupted materials amounted to 90 to $97 \times 10^{6} \mathrm{~m}^{3}$ of water equivalent. The volcanically generated flows entrained the seasonal snow on the lower glacier surface and Drift River valley, totalling about $35 \times 10^{6} \mathrm{~m}^{3}$ of water equivalent. Incorporation of seasonal snow increased the water content of the flows by about $27 \%$ at the point where the flow reached the head of the fan at the mountain front. The incorporated snow instigated a continuous compositional, 
and therefore rheological, change along the entire flowpath. However, as the flows debouched onto the relatively low-gradient Drift River flood plain, a slurry was deposited along channel margins, and the flows both debulked and attenuated, while more snow was being incorporated. These processes generated the largest flows in the Drift River during this century (Major and Janda, 1990). The flow was two orders of magnitude greater than the estimated 100 year flood for this river.

Continuous runoff from the summit area began after the first eruption in December 1989 and was assumed to be the result of melting caused by the proximity of hot rocks and remnant ice in the summit crater. The runoff helped incise the channels in the ice at the head of the piedmont lobe between eruption-pulsed changes. Repeated assessments of photos and observations from reconnaissance flights revealed no evidence of subsidence crevasses, which would indicate storage and release of large volumes of subglacial meltwater at any time during the eruptive series.

The 1989-90 and 1966-68 beheadings of "Drift" Glacier were similar. However, the 1989-90 eruption resulted in about twice the ice loss from "Drift" Glacier. The 1966-68 eruption produced perturbations in the flow of "Drift" Glacier that lasted for more than two decades (Sturm and others, 1986). A longer recovery period is expected following the 1989-90 eruption. Varying ash thicknesses on many glaciers within several tens of kilometers of Redoubt Volcano are expected to affect their mass balances, runoffs, and ice-flow regimes for the next several decades as well.

\section{ACKNOWLEDGEMENTS}

The photographic and videotaped record of the eruption of Redoubt Volcano was supported by the staff of the Alaska Volcano Observatory office in Anchorage and Fairbanks, Alaska.

\section{REFERENCES}

Brantley, S.R., ed. 1990. The eruption of Redoubt Volcano, Alaska, December 14, 1989-August 31, 1990. U.S. Geol. Surv. Circ. 1061.

Gardner, C.A. and C.A. Neal. 1990. Stratigraphy of proximal pyroclastic deposits from the eruption of Redoubt Volcano, Alaska, December 14, 1989-April 21, 1990. Eos, 71(43), 1706.

Laenen, A. and R. P. Hansen. 1988. Simulation of three lahars in the Mount St Helens area, Washington using a one-dimensional, unsteady-state streamflow model. U.S. Geol. Surv. Water-Resources Investigations Report 884004.

Major, J.J. and R.J. Janda. 1990. Channel instability induced by debris flows and floods during the 1989-90 eruptions of Redoubt Volcano, Alaska. Eos, 71(43), 1706.

Major, J.J. and C. G. Newhall. 1989. Snow and ice perturbation during historical volcanic eruptions and the formation of lahars and floods. A global review. Bull. Volcanol., 52(1), 1-27.

Sturm, M., C. Benson and P. MacKeith. 1986. Effects of the 1966-68 eruptions of Mount Redoubt on the flow of Drift Glacier, Alaska, U.S.A. J. Glaciol., 32(112), 355-362.

Waitt, R. B., J.J. Major, T. P. Miller and D. C. Trabant. 1990a. Effects of eruptions of Redoubt Volcano, Alaska between December 1989 and April 1990 on Drift Glacier. Eos, 71 (43), 1706.

Waitt, R. B. and 7 others. 1990b. Unusual ice conglomerate emplaced during the 15 December 1989 eruption of Redoubt Volcano, Alaska. Eos, 71 (43), 1706.

The accuracy of references in the text and in this list is the responsibility of the author/s, to whom queries should be addressed. 